\title{
"Impact of leadership behavior on psychological capital: the mediating role of organizational support"
}

\begin{tabular}{|c|c|}
\hline AUTHORS & $\begin{array}{l}\text { Osama Marashdah (D https://orcid.org/0000-0001-9996-3111 } \\
\text { Rokaya Albdareen (D https://orcid.org/0000-0002-8859-7117 }\end{array}$ \\
\hline ARTICLE INFO & $\begin{array}{l}\text { Osama Marashdah and Rokaya Albdareen (2020). Impact of leadership behavior } \\
\text { on psychological capital: the mediating role of organizational support. Problems } \\
\text { and Perspectives in Management, 18(2), 46-56. doi:10.21511/ppm.18(2).2020.05 }\end{array}$ \\
\hline DOI & http://dx.doi.org/10.21511/ppm.18(2).2020.05 \\
\hline RELEASED ON & Friday, 24 April 2020 \\
\hline RECEIVED ON & Saturday, 11 January 2020 \\
\hline ACCEPTED ON & Sunday, 29 March 2020 \\
\hline LICENSE & $\begin{array}{l}(\mathrm{cc}) \mathbf{E Y} \\
\text { This work is licensed under a Creative Commons Attribution } 4.0 \text { International } \\
\text { License }\end{array}$ \\
\hline JOURNAL & "Problems and Perspectives in Management" \\
\hline ISSN PRINT & $1727-7051$ \\
\hline ISSN ONLINE & $1810-5467$ \\
\hline PUBLISHER & LLC "Consulting Publishing Company "Business Perspectives" \\
\hline FOUNDER & LLC "Consulting Publishing Company "Business Perspectives" \\
\hline$\sigma^{0}$ & 三: \\
\hline NUMBER OF REFERENCES & NUMBER OF FIGURES \\
\hline 47 & 11 \\
\hline
\end{tabular}

(c) The author(s) 2021. This publication is an open access article. 


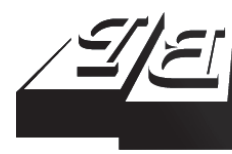

\section{BUSINESS PERSPECTIVES}

(O)

LLC "CPC "Business Perspectives" Hryhorii Skovoroda lane, 10, Sumy, 40022, Ukraine www.businessperspectives.org
Received on: $11^{\text {th }}$ of January, 2020 Accepted on: $29^{\text {th }}$ of March, 2020 Published on: $24^{\text {th }}$ of April, 2020

( ) Osama Marashdah, Rokaya Albdareen, 2020

Osama Marashdah, Ph.D. Student, Faculty of Business, Department of Business Administration, Jadara University, Irbid, Jordan.

Rokaya Albdareen, Ph.D Associate Professor, Faculty of Business, Department of Business Administration, Jadara University, Irbid, Jordan. (Corresponding author)
This is an Open Access article, distributed under the terms of the Creative Commons Attribution 4.0 International license, which permits unrestricted re-use, distribution, and reproduction in any medium, provided the original work is properly cited.

Conflict of interest statement: Author(s) reported no conflict of interest

\section{IMPACT OF LEADERSHIP BEHAVIOR ON PSYCHOLOGICAL CAPITAL: THE MEDIATING ROLE OF ORGANIZATIONAL SUPPORT}

\begin{abstract}
Even though psychological capital has been identified as an important issue in the workplace, little research has focused on it through organizational support. Drawing on leadership theory and conservation of resources theory, this article examines the mediating role of organizational support in the relationship between leadership behavior and psychological capital in insurance companies in Jordan. The questionnaires were distributed randomly. Out of 350 questionnaires, 335 questionnaires were effective for analysis, after analyzing the data using the statistical program SmartPLS version 3.2.6. Based on the theories, a significant impact of organizational support on the relationship between leadership behavior and psychological capital of employees was found. Thus, the study recommended maintaining the interest of senior management in the insurance companies operating in Jordan to identify and educate the managers of these companies in choosing the appropriate leadership behavior in accordance with the company's data and the circumstances surrounding it at the right time and place.
\end{abstract}

\section{Keywords}

JEL Classification organizational trust, flexibility, transformational leadership, organizational justice, insurance companies, Jordan

M12, D23

\section{INTRODUCTION}

Business organizations are becoming more and more interested in their human resources due to their role in the progress and development of the organization, achieve a competitive position, and, therefore, have to invest in their human resources and work on training and education and develop for a distinctive human resource. Hence, business organizations have to work to increase attention and take note of all aspects related to human resources (Al-Bdareen \& Khasawneh, 2019). The most important is the psychological aspect, or the so-called psychological capital, which is the state of mind, emotion, and impulse that the individual has in his organization, where this situation affects directly his productivity and ability to give and do the job to the best (Avey, Wernsing, \& Luthans, 2008). In the present serious business conditions, keeping the workers empowers the relationship to be fruitful. Representatives are seen as one of the most significant resources for most associations, specifically service-based associations, given the advantages of conveying effective exhibitions. One of the most significant assistance-based associations is the inn business. The inn business is a work-concentrated help industry, reliant on the accessibility of good quality representatives to convey, work, and deal with the traveler item for endurance and an upper hand (Amoah \& Baum, 1997).

The important role of leadership behavior, especially transformational, interactive, and ethical behavior, as well as the role of organizational support in satisfying the psychological needs of individuals, increases 
the level of psychological well-being and satisfaction of employees. Making them more hopeful and optimistic, and more flexible and efficient when carrying out their work tasks, increases the level of organizations owning psychological capital. The positive impact of transformational leadership, interactive leadership, and ethical leadership in these companies, and the impact of this kind of leadership behaviors on psychological capital, in addition to recognizing the intermediary role of organizational support, improve the relationship between leadership behavior and psychological capital. The tough competition between organizations for survival and continuity has increased the burdens placed on their workforce, thereby increasing the psychological, mental, and emotional stress that workers may be exposed to, and the thinking of some categories of them, especially those qualified and competent to leave the work. Hence, it became obligatory that leaders of these organizations should adopt leadership behaviors that lead to raising the morale of employees by providing all forms of psychological and emotional support, and, thus, the emergence of the so-called psychological capital in which individuals are more hopeful and optimistic, more flexible and efficient in dealing with the changes they may face ( AL-Badareen \& Al-Ghazzawi, 2018). It may be achieved by providing organizational support that makes an individual feel that the organization provides him with material and moral returns that enable him to satisfy his needs and achieve his ambitions, and commensurate with the size. His efforts, which are the returns that may be provided by providing adequate financial incentives, and the opportunity for individuals to develop and career progress, demonstrate confidence in the knowledge and capabilities they possess by increasing their level of empowerment and empowering them to carry out their work tasks, and involving them in the decision-making processes at the level of the organization and decisions related to their functions.

Given the leadership behavior and the level of organizational support that may significantly affect the possession of psychological capital that enables them to achieve the desired competitive advantage, this study came to identify the extent of the practice of positive leadership behaviors, and the level of organizational support in a group of companies operating in the insurance sector, and its impact on the acquisition of the required psychological capital, as all the workers in this type of companies still suffer from lack of support, isolation from the decision-making processes, and holding them more responsibilities for the results achieved, which may affect their sense of psychological satisfaction negatively, and therefore possessing the so-called psychological capital, which enables them to achieve a competitive position, especially as the type of companies operating in a highly competitive environment (Chhabra \& Pattanayak, 2017).

\section{LITERATURE REVIEW AND HYPOTHESES DEVELOPMENT}

This study investigated three main topics: leadership behavior, organizational support, and psychological capital. The study also indicated the importance of each topic and its dimensions.

\subsection{Leadership behavior}

There is an important role for leadership behavior in raising the morale of employees and motivating them, in training and development to achieve the best output, whether it is a product or service, and compete with other organizations (Aljawarneh \& Atan, 2018). The dimensions of leadership be- havior are transformational leadership, ethical leadership, and transactional leadership. The researchers differed in determining the definition of transformational leadership due to the different philosophies and views that dealt with this concept, and the fact that this concept is considered a modern concept in management. Lawton and Páez (2014) defined transformational leadership as "the method or way in which the leader motivates employees and improves their level through training and gaining experience to achieve the objectives of the organization". Ghasabeh, Soosay, and Reaiche (2015) also cited that it is a leadership pattern that generates new knowledge and ideas through intellectual stimulation for individuals to deal with problems in modern ways. There are several dimensions of transformational leadership (Ghasabeh, Soosay, \& Reaiche, 2015; Al-Omari, 
Alomari, \& Aljawarneh, 2020; Deinert, Homan, Boer, Voelpel, \& Gutermann, 2015): ideal impact, individual considerations, motivation, effectiveness of decision-making process, empowerment, and intellectual excitement.

Some researchers defined ethical leadership as the leadership style in which the leader depends on ethics in carrying out the work tasks, where the commander entrenches the principle of ethics of the employees, and in such a way that every employee does what is dictated by his conscience and morals, and, thus, the employee works without the need for a watchdog because he does his work following his leader, does not accept complacency or error in work under any circumstances (Wang, Liu, Zou, Hao, \& Wu, 2017). Northouse (2013) points out that the dimensions of ethical leadership originally belong to Aristotle Thales, and these dimensions were discussed and defined as follows: respect, serving others, justice, honesty and integrity, sharing power ( Lawton \& Páez, 2014; Mo \& Shi, 2015).

As for transactional leadership, Chunharas and Davies (2016) believe that subordinates no longer receive orders only from senior management but also have the opportunity to influence and reshape decisions of decision-makers positively. This is because the subordinates are allowed to interact with senior management in the decision-making process. Dimensions affecting interactive leadership are interactive leadership and its application on the ground influenced by several dimensions that provide the appropriate environment to ensure its application and its impact on subordinates, such as climate change (Klaussner, 2012), which met the degree of intimacy between subordinates and the size of the working group.

\subsection{Organizational support}

The term emerged in the 1980s, but it was unsure despite its circulation in the administrative literature for nearly 70 years (Beheshtifar \& Zare, 2012). Organizational support, as stated by Adams and Mastracci (2018), is the belief of staff that they are treated fairly and impartially by the organization in terms of supervisory support, fairness, remuneration, job conditions, or whatever the employee expects to be treated appropriately. Many researchers agreed that there are several personal, environ- mental, and regulatory factors that play a large and effective role in stabilizing employees' sense of organizational support. These factors are organizational trust, reward, and organizational justice.

\subsubsection{Organizational trust}

Organizational trust reflects the perceptions and expectations of individuals and groups about the organization's commitment to its promises, decisions, and agreements to achieve public and private goals (Beheshtifar \& Zare, 2012). Organizational trust is a strong bridge between the organization and its staff. It is one of the most important elements of organizational support, where every employee does what he needs, and he is sure that the organization appreciates its efforts and is commitment (Rabelo, Holland, \& Cortina, 2016).

\subsubsection{Reward}

Motivation is the thing that gives the desire or impulse to work seriously, where the incentives affect human life and determine the behavior and direction, as it reflects the satisfaction of employees of the organization, given its appreciation of the work they do, which leads to increased productivity and ability of individuals (Carlstedt et al., 2018).

\subsubsection{Organizational justice}

The emergence of the concept of organizational justice is due to the theory of equality, which started from the idea that individuals judge the level of justice in the organization through the employee's process of comparing the employee himself with his colleagues, in terms of efforts made by him and his colleagues. The return, whether material or moral, is achieved as a result of these efforts, where the individual assesses the nature of the work required of him and his colleagues and how to accomplish, and whether the distribution of work and returns is fair and proportionate to the effort exerted by each of them, organizational justice is a positive perception, which leads to the emergence of collective behaviors of cooperative joint, and contributes to the reduction of labor turnover and ensuring the rights of individuals and groups, and the absence of such justice usually leads to distrust and dissatisfaction and, thus. lower performance in general (Ouyang, Sang, Li, \& Peng, 2015). 


\subsection{Psychological capital}

The term "psychological capital" emerged in the studies conducted by Maslow. Most studies have also agreed that the term "psychological capital" is one of the concepts included in economics, sociology, and psychology. So, it has the term "psychological capital" first emerged by Goldsmith and then crystallized this concept more clearly in the work of Seligman (Rego, Sousa, Marques, \& Pina e Cunha, 2002), where he relied on the study in the psychological field, such as mental disorders and mental illness, the shift from negative to positive, and in 2004, the term was used. The scientist Fred Luthans explicitly combined psychological capital with organizational behavior in order for the latter to become positive. He was most credited with the emergence of this term and developed this term to show what is called positive psychological capital (Yim, Seo, Cho, \& Kim, 2017). The positive conditions, perseverance, and best efforts to achieve the goals of the organization efficiently and effectively, represent the individual's positive psychological state.

The importance of psychological capital lies in the fact that it helps to reduce stress and pressure on individuals and reduce the costs and negative effects for the organization. There is a positive relationship between the psychological capital, the attitudes of employees, and the performance of their work tasks efficiently and effectively. There is a negative relationship between psychological capital and job combustion, which means that psychological capital contributes to reducing the level of job burnout that workers may experience, especially those with qualifications and competencies, and thus leads them to consider leaving work and seeking alternative work in competing organizations (Avey, Wernsing, \& Luthans, 2008; Aljawarneh \& Atan, 2018; Avey, Nimnicht, \& Pigeon, 2010; Spence Laschinger \& Fida, 2014).

Several studies, the most important of which are Luthans and Jensen (2005), which is considered the pioneer in psychology concerning psychological capital, have shown that several dimensions make up psychological capital (hope, optimism, effectiveness). These dimensions can be illustrated in more detail as follows (Avey, Nimnicht, \& Graber Pigeon, 2010; A. Caza, Bagozzi, Woolley, Levy, \& B. Caza, 2010; Spence Laschinger \& Fida, 2014).
Optimism is expressed in the way of thinking about the future, where it is possible to associate feelings, whether positive or negative, to think about the future, and when the feelings are positive, a sense within the individual is called optimism (Luthans \& Jensen, 2005). Hope is a feeling of the positive psyche that makes an individual persevering to achieve his goals, and in case of failure, he searches for more than one way or method to reach it (Javidan \& Walker, 2012).

Self-actualization, when this term appears in the administrative sciences, has been defined as having the individual's confidence in his abilities, using his knowledge resources to control and manage his motivation to achieve the goals successfully (Yim, Seo, Cho \& Kim, 2017). The process of self-realization also refers to learning and gaining experience through the use of observing the behavior of others and dealing with others within the context of building social relationships (Aljawarneh \& Atan, 2018).

Flexibility is the ability of the individual to return to the normal situation after exposure to crises and problems. In the course of the completion of the tasks required of it and achieving its goal, flexibility is a positive characteristic and a great advantage that enables the individual to face difficulties and crises to achieve the goals. Common features are the acceptance of reality in all its variables, the presence of self-confidence and abilities possessed by the individual, and keeping up with the important and surrounding changes and trying to adapt to them are directly linked to change and face the instability surrounding the individual (Luthans \& Jensen, 2005; Rego, Sousa, Marques, \& Pina e Cunha, 2012). Based on theoretical literature and previous studies, the reasrchers has reached the following hypotheses:

H1: Leadership behavior has a positive impact on psychological capital.

H2: Leadership behavior has a positive impact on organizational support.

H3: Organizational support has a positive impact on psychological capital.

H4: Organizational support mediates the relationship between leadership behavior and psychological capital. 


\section{METHODS}

The study relied on the survey method, which includes the use of the field method for collecting data. There are 3,124 employees in insurance companies in Amman (Jordan Insurance Federation, 2017). The researcher drew a simple random sample from the study population of 350 employees depending on the total size of the study population and margin of error allowed (Sekaran \& Bougie, 2015), which was distributed to insurance companies in Amman over 14 days, and 338 questionnaires were retrieved. The unit of analysis in this study was represented by each employee working in insurance companies in Amman and was selected within the sample of the study. As for the validity of the measuring instrument, the coefficient of Cronbach Alpha for internal consistency was extracted for all the study measures. Most studies have indicated that acceptance of the coefficient of validity is more than 0.70 (Sekaran \& Bougie, 2015).

Table 1. Cronbach Alpha method for study tool areas

\begin{tabular}{|c|c|c|c|}
\hline Field & $\begin{array}{l}\text { Number of } \\
\text { paragraphs }\end{array}$ & Dimension & $\begin{array}{c}\text { Cronbach } \\
\text { Alpha }\end{array}$ \\
\hline \multirow{4}{*}{ 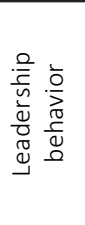 } & 6 & $\begin{array}{c}\text { Transformational } \\
\text { leadership }\end{array}$ & 0.944 \\
\hline & 6 & Ethical leadership & 0.922 \\
\hline & 6 & Interactive leadership & 0.908 \\
\hline & 18 & Leadership behavior & 0.969 \\
\hline \multirow{5}{*}{ 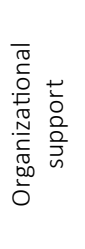 } & 4 & Organizational trust & 0.899 \\
\hline & 5 & Reward & 0.946 \\
\hline & 5 & Organizational justice & 0.925 \\
\hline & 5 & Self-actualization & 0.949 \\
\hline & 19 & Organizational support & 0.975 \\
\hline \multirow{5}{*}{ 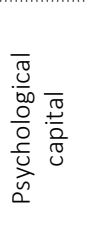 } & 5 & Hope & 0.913 \\
\hline & 5 & Optimism & 0.923 \\
\hline & 5 & Flexibility & 0.902 \\
\hline & 5 & Self-efficacy & 0.931 \\
\hline & 20 & Psychological capital & 0.968 \\
\hline
\end{tabular}

\section{RESULTS}

Results related to describing the type of leadership behavior, organizational support, and psychological capital were used in insurance companies. Arithmetic averages and standard deviations have been calculated for the consent of the respondents to the paragraphs related to the level of leadership behavior, organizational support, and psychological capital required in the insurance companies in Amman. The results were shown in Table 2.

Table 2. Means and standard deviations of study variables

\begin{tabular}{|c|c|c|c|c|c|}
\hline Rank & Number & Dimension & SMA & SD & $\begin{array}{c}\text { Ranking } \\
\text { score }\end{array}$ \\
\hline 1 & 1 & $\begin{array}{l}\text { Transformational } \\
\text { leadership }\end{array}$ & 3.83 & 0.95 & High \\
\hline 2 & 3 & $\begin{array}{l}\text { Interactive } \\
\text { leadership }\end{array}$ & 3.72 & 0.86 & High \\
\hline 3 & 2 & Ethical leadership & 3.61 & 1.00 & Medium \\
\hline \multicolumn{3}{|c|}{ Leadership behavior } & 3.72 & 0.89 & High \\
\hline 1 & 4 & Self-actualization & 3.74 & 1.02 & High \\
\hline 2 & 1 & Organizational trust & 3.69 & 0.92 & High \\
\hline 3 & 3 & $\begin{array}{l}\text { Organizational } \\
\text { justice }\end{array}$ & 3.61 & 0.98 & Medium \\
\hline 4 & 2 & Reward & 3.58 & 1.02 & Medium \\
\hline \multicolumn{3}{|c|}{ Organizational support } & 3.66 & 0.94 & High \\
\hline 1 & 4 & Self-efficacy & 4.12 & 0.80 & High \\
\hline 2 & 3 & Flexibility & 4.09 & 0.78 & High \\
\hline 3 & 1 & Hope & 4.04 & 0.82 & High \\
\hline 4 & 2 & Optimism & 3.81 & 0.94 & High \\
\hline \multicolumn{3}{|c|}{ Psychological capital } & 3.66 & 0.94 & High \\
\hline
\end{tabular}

It is noted from Table 2 that the mean for the approval of the study sample members in the level of practicing the required leadership behavior in the insurance companies researched ranged between 3.61 and 3.83, with high evaluation score. Organizational support ranged between 3.58 and 3.74 , with high evaluation score, second came Psychological capital with an average between 3.81 and 4.12, with high evaluation score of all dimensions. The results also showed that the overall level of availability of dimensions in the researched companies was high because of the psychological stability experienced by the employees of the insurance companies in Amman.

To verify the objectivity of the study results, Kolmogorov-Smirnov test was performed to verify that the study data are free from statistical problems that may adversely affect the results of the hypothesis testing. The normal distribution ratios for all the responses were greater than 0.05 , which is the level used in the statistical treatment of this study, as some studies indicated, the distribution is normal when the level of $\alpha \leq 0.05$ (Sekaran, 2006). 
Table 3. Normal distribution of study variables (K-S test)

\begin{tabular}{|c|c|c|c|c|}
\hline Field & Dimension & K-S & Sig.* & Result \\
\hline \multirow{3}{*}{ 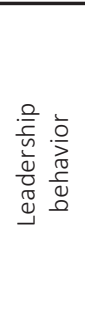 } & $\begin{array}{l}\text { Transformational } \\
\text { leadership }\end{array}$ & 1.15 & 0.14 & $\begin{array}{l}\text { Natural } \\
\text { distribution } \\
\text { follows }\end{array}$ \\
\hline & Ethical leadership & 1.25 & 0.07 & $\begin{array}{l}\text { Natural } \\
\text { distribution } \\
\text { follows }\end{array}$ \\
\hline & $\begin{array}{l}\text { Interactive } \\
\text { leadership }\end{array}$ & 1.00 & 0.27 & $\begin{array}{l}\text { Natural } \\
\text { distribution } \\
\text { follows }\end{array}$ \\
\hline \multirow{4}{*}{ 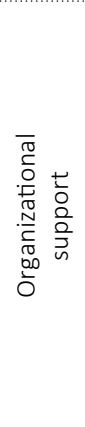 } & $\begin{array}{l}\text { Organizational } \\
\text { trust }\end{array}$ & 1.29 & 0.08 & $\begin{array}{l}\text { Natural } \\
\text { distribution } \\
\text { follows }\end{array}$ \\
\hline & Reward & 1.14 & 0.15 & $\begin{array}{l}\text { Natural } \\
\text { distribution } \\
\text { follows }\end{array}$ \\
\hline & $\begin{array}{l}\text { Organizational } \\
\text { justice }\end{array}$ & 0.89 & 0.40 & $\begin{array}{l}\text { Natural } \\
\text { distribution } \\
\text { follows }\end{array}$ \\
\hline & Self-actualization & 0.88 & 0.41 & $\begin{array}{l}\text { Natural } \\
\text { distribution } \\
\text { follows }\end{array}$ \\
\hline \multirow{4}{*}{ 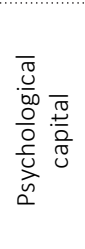 } & Hope & 0.91 & 0.42 & $\begin{array}{l}\text { Natural } \\
\text { distribution } \\
\text { follows }\end{array}$ \\
\hline & Optimism & 0.89 & 0.43 & \multirow{3}{*}{$\begin{array}{l}\text { Natural } \\
\text { distribution } \\
\text { follows }\end{array}$} \\
\hline & Flexibility & 0.88 & 0.44 & \\
\hline & Self-efficacy & 0.89 & 0.45 & \\
\hline
\end{tabular}

Quality indicators conforming to the structural model were extracted, and the results were shown in Table 4.

Table 4. Model fit quality indicators for data

\begin{tabular}{|c|c|c|c|}
\hline Indicator & $\begin{array}{l}\text { Admission } \\
\text { standard }\end{array}$ & $\begin{array}{c}\text { Indicator } \\
\text { value }\end{array}$ & Result \\
\hline $\begin{array}{l}\text { The square root of the } \\
\text { remaining standard mean }\end{array}$ & $\begin{array}{l}\text { Less than } \\
0.08\end{array}$ & 0.05 & Acceptance \\
\hline $\begin{array}{l}\text { Comparative matching } \\
\text { index }\end{array}$ & $\begin{array}{c}\text { Greater than } \\
0.09\end{array}$ & 2.31 & Acceptance \\
\hline $\begin{array}{l}\text { The square root of the } \\
\text { approach error }\end{array}$ & $\begin{array}{l}\text { Less than } \\
\quad 0.12\end{array}$ & 0.09 & Acceptance \\
\hline
\end{tabular}

Table 4 shows that all indicators used to assess the validity of the model are acceptable values (Amir \& Souderpandian, 2002).

To verify the validity of the first main hypothesis and its sub-hypotheses, the researcher extracted the Pearson correlation coefficient to determine a significant relationship between the independent variable and its different dimensions, on the one hand, and the dependent variable, on the other hand. The results were shown in Table 5.
Table 5. Pearson correlation between leadership behavior and psychological capital

\begin{tabular}{|c|c|c|}
\hline $\begin{array}{l}\text { Independent } \\
\text { variable }\end{array}$ & $\begin{array}{c}\text { Correlation } \\
\text { coefficient/ } \\
\text { statistical } \\
\text { significance }\end{array}$ & $\begin{array}{c}\text { Psychological } \\
\text { capital }\end{array}$ \\
\hline Transformational & $\begin{array}{l}\text { Correlation } \\
\text { coefficient }\end{array}$ & 0.76 \\
\hline Leadership & $\begin{array}{l}\text { Statistical } \\
\text { significance }\end{array}$ & 0.00 \\
\hline \multirow{2}{*}{ Interactive leadership } & $\begin{array}{l}\text { Correlation } \\
\text { coefficient }\end{array}$ & 0.73 \\
\hline & $\begin{array}{c}\text { Statistical } \\
\text { significance }\end{array}$ & 0.00 \\
\hline \multirow{2}{*}{ Ethical leadership } & $\begin{array}{l}\text { Correlation } \\
\text { coefficient }\end{array}$ & 0.78 \\
\hline & $\begin{array}{c}\text { Statistical } \\
\text { significance }\end{array}$ & 0.00 \\
\hline \multirow{2}{*}{ Leadership behavior } & $\begin{array}{l}\text { Correlation } \\
\text { coefficient }\end{array}$ & 0.81 \\
\hline & $\begin{array}{l}\text { Statistical } \\
\text { significance }\end{array}$ & 0.08 \\
\hline
\end{tabular}

There is a strong relationship between the leadership behavior and the psychological capital in insurance companies, where the value of the correlation coefficient was 0.81 , a statistically significant value; therefore, the hypothesis is accepted and indicates an impact of leadership behavior on psychological capital. The researcher applied the multiple regression, where the results are shown in Table 6.

Table 6. The multiple regression results between leadership behavior and psychological capital

\begin{tabular}{|c|c|c|c|c|c|c|c|}
\hline Variable & Beta & $\mathbf{T}$ & $\mathbf{P}$ & $\mathbf{R}$ & $R^{2}$ & $\mathbf{F}$ & $\mathbf{P}$ \\
\hline $\begin{array}{l}\text { Transformational } \\
\text { leadership }\end{array}$ & 0.34 & 5.36 & 0.00 & \multirow{3}{*}{0.81} & \multirow{3}{*}{0.65} & \multirow{3}{*}{205.18} & \multirow{3}{*}{0.00} \\
\hline Interactive leadership & 0.06 & 0.81 & 0.42 & & & & \\
\hline Ethical leadership & 0.44 & 6.16 & 0.00 & & & & \\
\hline
\end{tabular}

Table 6 shows the effect of leadership behavior on psychological capital. The correlation coefficient value was 0.81 , and the value of $R^{2}$ was 0.65 , which shows the impact of leadership behavior on psychological capital.

To validate the second main hypothesis and the sub-hypotheses originating from it, the researcher extracted the Pearson correlation coefficient to determine a significant relationship between the independent variable and its different dimensions, on the one hand, and the median variable, on the other hand. The results were shown in Table 7. 
Table 7. Pearson correlation coefficient results for the relationship between leadership behavior and organizational support

\begin{tabular}{|c|c|c|}
\hline $\begin{array}{l}\text { Independent } \\
\text { variable }\end{array}$ & $\begin{array}{l}\text { Correlation coefficient// } \\
\text { statistical significance }\end{array}$ & $\begin{array}{c}\text { Organizational } \\
\text { support }\end{array}$ \\
\hline \multirow{2}{*}{$\begin{array}{l}\text { Transformational } \\
\text { leadership }\end{array}$} & Correlation coefficient & 0.84 \\
\hline & Statistical significance & 0.00 \\
\hline \multirow{2}{*}{$\begin{array}{l}\text { Interactive } \\
\text { leadership }\end{array}$} & Correlation coefficient & 0.85 \\
\hline & Statistical significance & 0.00 \\
\hline \multirow{2}{*}{ Ethical leadership } & Correlation coefficient & 0.89 \\
\hline & Statistical significance & 0.00 \\
\hline \multirow{2}{*}{$\begin{array}{l}\text { Leadership } \\
\text { behavior }\end{array}$} & Correlation coefficient & 0.91 \\
\hline & Statistical significance & 0.00 \\
\hline
\end{tabular}

Table 7 shows that there is a relationship between leadership behavior and organizational support. The correlation coefficient is 0.91 , which is statistically significant, thus accepting the hypothesis between leadership behavior and organizational support. To demonstrate the effect, the multiple regression equation was applied, where the results were shown in Table 8.

Table 8. The results of applying the multiple regression equation to study the impact of leadership behavior in organizational support

\begin{tabular}{|c|c|c|c|c|c|c|c|}
\hline Variable & Beta & $\mathbf{T}$ & $\mathbf{P}$ & $\mathbf{R}$ & $R^{2}$ & $\mathbf{F}$ & $\mathbf{P}$ \\
\hline $\begin{array}{l}\text { Transformational } \\
\text { leadership }\end{array}$ & 0.28 & 6.33 & 0.00 & \multirow{3}{*}{0.91} & \multirow{3}{*}{0.83} & \multirow{3}{*}{538.52} & \multirow{3}{*}{0.00} \\
\hline Ethical leadership & 0.18 & 5.53 & 0.00 & & & & \\
\hline $\begin{array}{l}\text { Interactive } \\
\text { leadership }\end{array}$ & 0.50 & 9.88 & 0.00 & & & & \\
\hline
\end{tabular}

Table 8 shows the effect of leadership behavior on organizational support. The correlation coefficient value was 0.91 , which is statistically significant and indicates the degree of correlation between the dimensions of the independent variable combined and the mediating variable, $83 \%$ of the change in organizational support, and the value of the F-test 538.52, a statistically significant value indicating the impact of leadership behavior on organizational support.

To examine the third hypothesis, Pearson correlation coefficient was extracted to determine a significant correlation between the intermediate variable and its various dimensions on dependent variable, and the results were shown in Table 9.
Table 9. Pearson correlation coefficient results for the relationship between organizational support and psychological capital

\begin{tabular}{|c|c|c|}
\hline $\begin{array}{l}\text { Psychological } \\
\text { capital }\end{array}$ & $\begin{array}{c}\text { Correlation coefficient/ } \\
\text { statistical significance }\end{array}$ & $\begin{array}{c}\text { Independent } \\
\text { variable }\end{array}$ \\
\hline \multirow{2}{*}{$\begin{array}{l}\text { Organizational } \\
\text { trust }\end{array}$} & Correlation coefficient & 0.74 \\
\hline & Statistical significance & 0.00 \\
\hline \multirow{2}{*}{ Reward } & Correlation coefficient & 0.70 \\
\hline & Statistical significance & 0.00 \\
\hline \multirow{2}{*}{$\begin{array}{l}\text { Organizational } \\
\text { justice }\end{array}$} & Correlation coefficient & 0.77 \\
\hline & Statistical significance & 0.00 \\
\hline Self-actualization & Correlation coefficient & 0.79 \\
\hline \multirow{2}{*}{$\begin{array}{l}\text { Organizational } \\
\text { support }\end{array}$} & Statistical significance & 0.00 \\
\hline & Correlation coefficient & 0.82 \\
\hline $\begin{array}{l}\text { Organizational } \\
\text { trust }\end{array}$ & Statistical significance & 0.00 \\
\hline
\end{tabular}

Table 9 shows that there is a strong correlation between organizational support and psychological capital. The correlation coefficient was 0.82 , which is statistically significant and, therefore, accepts the hypothesis. To indicate whether there is an effect of organizational support on psychological capital, the multiple regression was applied, where the results are shown in Table 10.

Table 10. The results of applying the multiple regression equation to study the impact of organizational support on psychological capital

\begin{tabular}{|c|c|c|c|c|c|c|c|}
\hline Variable & Beta & $\mathbf{T}$ & $\mathbf{P}$ & $\mathbf{R}$ & $R^{2}$ & $\mathbf{F}$ & $\mathbf{P}$ \\
\hline $\begin{array}{l}\text { Organizational } \\
\text { trust }\end{array}$ & 0.25 & 3.97 & 0.00 & \multirow{4}{*}{0.82} & \multirow{4}{*}{0.68} & \multirow{4}{*}{171.40} & \multirow{4}{*}{0.00} \\
\hline Reward & 0.04 & 0.62 & 0.54 & & & & \\
\hline $\begin{array}{l}\text { Organizational } \\
\text { justice }\end{array}$ & 0.25 & 3.57 & 0.00 & & & & \\
\hline Self-actualization & 0.41 & 6.53 & 0.00 & & & & \\
\hline
\end{tabular}

The value of the correlation coefficient is 0.82 , which is statistically significant and indicates the degree of correlation between the dimensions of the intermediate variable and the dependent variable. The value of $R^{2}$ is 0.68 , which is a statistically significant value, which means that the organizational support explains $68 \%$ of the variable in the psychological capital, and the F-value 171.40 statistically indicative of the existence of the impact of regulatory support in the psychological capital. To verify the effect of organizational support as an intermediate variable in the relationship between leadership behavior and psycho- 


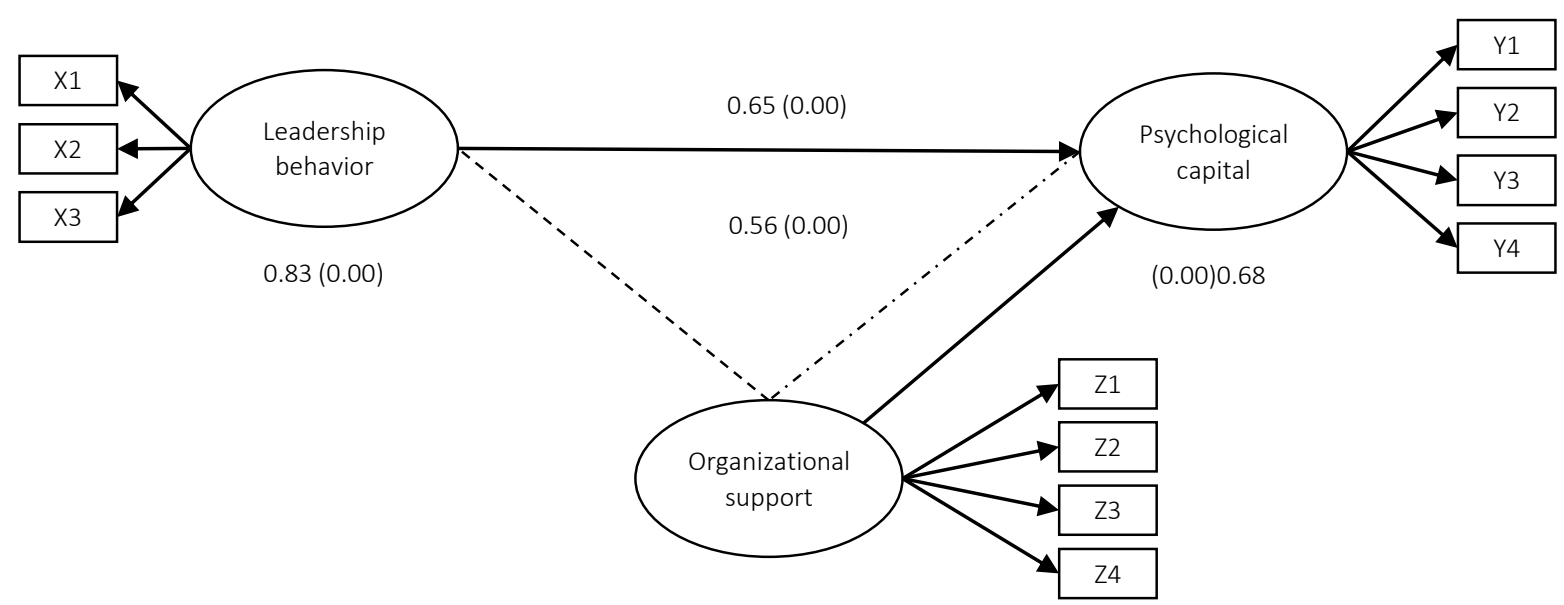

Figure 1. The role of organizational support in the relationship between leadership behavior and psychological capital

Table 11. Results of the path analysis to measure the impact of leadership behavior on psychological capital in the presence of organizational support as an intermediate variable

\begin{tabular}{|c|c|c|c|c|}
\hline \multirow{2}{*}{ Track } & Beta value & Beta value & \multirow{2}{*}{ T-value } & \multirow{2}{*}{$\mathbf{P}$} \\
\hline & Direct track & Indirect track & & \\
\hline Leadership behavior $\rightarrow$ Organizational support & 0.83 & & 24.218 & 0.02 \\
\hline Organizational support $\rightarrow$ Psychological capital & 0.68 & & 5.132 & 0.00 \\
\hline Leadership behavior $\rightarrow$ Psychological capital & 0.65 & & 6.283 & 0.00 \\
\hline Leadership behavior $\rightarrow$ Organizational support $\rightarrow$ Psychological capital & & 0.56 & 5.103 & 0.00 \\
\hline
\end{tabular}

logical capital, path analysis was used based on SMARTPLSV3.2.6. The test results are shown in Table 11 and Figure 1.

Table 11 shows that the direct impact of leadership behavior on psychological capital was 0.65 , with a statistically significant level of 0.00 , which is statistically significant, while the indirect effect of leadership behavior on psychological capital after entering the organizational support as a mediating variable was 0.56 , with a statistically significant level of 0.00 . This means that there is a statistically significant and partial mediation effect of organizational support in the relationship between leadership behavior and psychological capital, and that organizational support explains 56\% of the impact of leadership behavior on psychological capital.

\section{DISCUSSION}

There takes place statistically significant effect of the leadership behavior on the organizational support. This result is consistent with the results of Şahin, Çubuk, and Uslu's (2014) study, which showed a positive impact of transformational leadership on employee creativity and perceived organizational support, and this is also in accordance with the result of a study by Koh and Hia (1997) who found a positive impact of interactive leadership components (interaction skills, team building) on employees' confidence in their leaders, motivation of employees, and commitment of employees towards their companies. There is a strong correlation between organizational support and psychological capital, and this result is consistent with the result of the study by Wang et al. (2017) who found positive correlation between organizational support, psychological capital, and job integration, and also agreed with the result of the study by Şahin, Çubuk, and Uslu (2014) who found a positive correlation between organizational support and job performance, on the one hand, and the psychological capital of employees, on the other hand.

There is an impact of regulatory support on psychological capital. The direct impact of leadership behavior on psychological capital was 0.65 , with a statistical significance, and this result is consistent with the results of Şahin, Çubuk, and Uslu's (2014) 
study, which found a statistically significant effect of transformational leadership with its dimensions in the decision-making process, and also agreed with the result of the study by Koh and Hia (1997) who found a positive impact of interactive leadership components (interaction skills) and (team building) on staff confidence in their leaders, motivation, and commitment to staff. These companies differed with the result of a study by Şahin, Çubuk, and Uslu (2014) who concluded that there was no effect of transformational leadership on psychological capital and job performance.

\section{CONCLUSION}

This study has provided evidence and achieved its objective of examining the mediating role of organizational support in the relationship between leadership behavior and psychological capital. It has shown that the practice level of the positive leadership behaviors, organizational support and the availability level of the human capital in insurance companies in Jordan is high. The results also indicated that there is a strong and significant relationship between the leadership behavior and the psychological capital, where the value of the correlation coefficient was 0.81 . The results also showed that There is a relationship between leadership behavior and organizational support. The correlation coefficient is 0.91 , and There is a strong correlation between organizational support and psychological capital. The correlation coefficient is 0.82 .

The results of this study also indicated that the indirect impact of leadership behavior on psychological capital after organizational support as a mediate variable was 0.56 , with a statistical significance, which means that there is a statistically significant and partial mediation of organizational support in the relationship between leadership behavior and psychological capital. Organizational support explains the effect of leadership behavior on psychological capital at the level of $56 \%$.

\section{AUTHOR CONTRIBUTIONS}

Conceptualization: Osama Marashdah, Rokaya Albdareen.

Data curation: Rokaya Albdareen.

Formal analysis: Osama Marashdah.

Funding acquisition: Osama Marashdah.

Investigation: Rokaya Albdareen.

Supervision: Osama Marashdah.

Validation: Osama Marashdah.

Writing - original draft: Rokaya Albdareen.

Writing - review \& editing: Rokaya Albdareen.

\section{REFERENCES}

1. Adams, I., \& Mastracci, S. (2018). Police Body-Worn Cameras: Effects on Officers' Burnout and Perceived Organizational Support. Police Quarterly, 22(1), 5-30. https://doi. org/10.1177/1098611118783987

2. AL-Badareen, R., \& Al-Ghazzawi, H. (2018). Diversity Training and its Impact on the Employees Organizational Commitment: Job Satisfaction as a Moderating
Variable in the Classic Fashion Apparel Industry Company. International Journal of Business and Management, 13(10), 116128. http://doi.org/10.5539/ijbm. v13n10p116

3. Al-Bdareen, R., \& Khasawneh, H. (2019). Human resources staffing process and its impact on job involvement: Irbid District Electricity Company as a case study. Problems and Perspectives in Management, 17(2), 254266. https://doi.org/10.21511/ ppm.17(2).2019.19

4. Aljawarneh, N. M. S., \& Atan, T. (2018). Linking Tolerance to Workplace Incivility, Service Innovative, Knowledge Hiding, and Job Search Behavior: The Mediating Role of Employee Cynicism. Negotiation and Conflict 
Management Research, 11(4), 298-320. https://doi.org/10.1111/ ncmr.12136

5. Al-Omari, Z., Alomari, K., \& Aljawarneh, N. (2020). The role of empowerment in improving internal process, customer satisfaction, learning and growth. Management Science Letters, 10(4), 841-848. http://dx.doi.org/10.5267/j. msl.2019.10.013

6. Amir, D., \& Souderpandian, J. (2002). Complete Business Statistics (5th ed.). McGraw-Hill. Retrieved from https://www.amazon.com/ Complete-Statistics-Sounderpandian-McGraw-Hill-Hardcover/dp /B 0 0DU8677Y

7. Amoah, V. A., \& Baum, T. (1997). Tourism education: policy versus practice. International Journal of Contemporary Hospitality Management, 9(1), 5-12. https://doi. org/10.1108/09596119710157531

8. Avey, J. B., Nimnicht, J. L. \& Graber Pigeon, N. (2010). Two field studies examining the association between positive psychological capital and employee performance. Leadership \& Organization Development Journal, 31(5), 384-401. https://doi. org/10.1108/01437731011056425

9. Avey, J. B., Wernsing, T. S., \& Luthans, F. (2008). Can Positive Employees Help Positive Organizational Change? Impact of Psychological Capital and Emotions on Relevant Attitudes and Behaviors. The Journal of Applied Behavioral Science, 44(1), 48-70. https://doi.org/ $10.1177 / 00$ 21886307311470

10. Beheshtifar, M., \& Zare, E. (2012) Effect perceived organizational support on employees' attitudes toward work. Science Series Data Report, 4(9). Retrieved from https:// www.researchgate.net/ profile / Malikeh_Beheshtifar/publication/281176639_Effect_perceived_ organizational_support_on_employees'attitudes_toward_work/ links/55d9c6e908aed6a199a96cc1/ Effect-perceived-organizationalsupport-on-employees-attitudestoward-work.pdf

11. Carlstedt, A. B., Brushammar, G., Bjursell, C., Nystedt, P., \& Nilsson,
G. (2018). A scoping review of the incentives for a prolonged work life after pensionable age and the importance of "bridge employment". Work, 60(2), 175-189. https://doi. org/10.3233/WOR-182728

12. Caza, A., Bagozzi, R. P., Woolley, L., Levy, L., \& Caza, B. B. (2010). Psychological capital and authentic leadership: Measurement, gender, and cultural extension. Asia-Pacific Journal of Business Administration, 2(1), 53-70. https://doi. org/10.1108/17574321011028972

13. Chunharas, S., \& Davies, D. S. C. (2016). Leadership in health systems: a new agenda for interactive leadership. Health Systems \& Reform, 2(3), 176-178. https://doi.org/10.1080/23288604.20 16.1222794

14. Colquitt, J. A., Greenberg, J., \& Phelan, C. P. (2005). What is organizational justice? A historical overview. In J. Greenberg \& J. A. Colquitt (Eds.), Handbook of Organizational Justice (pp. 3-58). Lawrence Erlbaum Associates Publishers. Retrieved from https://psycnet.apa.org/record/2005-03594-001

15. Deinert, A., Homan, A. C., Boer, D., Voelpel, S. C., \& Gutermann, D. (2015). Transformational leadership sub-dimensions and their link to leaders' personality and performance. The Leadership Quarterly, 26(6), 1095-1120. https://doi.org/10.1016/j. leaqua.2015.08.001

16. Ghasabeh, M. S., Soosay, C., \& Reaiche, C. (2015). The emerging role of transformational leadership. Journal of Developing Areas, 49(6), 459-467. Retrieved from https:// econpapers.repec.org/ a r t i cle / jdajournl/vol.49_3ayear_3a2015_3ai ssue6_3app_3a459-467.htm

17. Jahangir, M., \& Abdullah, M. (2017). A Review of Organizational Silence antecedents and its impact on Job Attitudes. Sarhad Journal of Management Sciences, 3(1), 146-159. Retrieved from http://journal.suit. edu.pk/index.php/sjms/article/ view $/ 87 / 0$

18. Jaiswal, S. H., \& Joge, P) .2018). A study on impact of psychological empowerment on employee retention in technical institutes of Durg and Bhilai. International Journal of Research GRANTHAALAYAH, 6(1), 470-479. Retrieved from https://zenodo.org/ record/1172278\#.XoxrlsgzaUk

19. Javidan, M., \& Walker, J. L. (2012). A whole new global mindset for leadership. People and Strategy, 35(2), 36-41. Retrieved from https://www.researchgate.net/ publication/288959604_A_whole _new_global mindset_for_leadership

20. Ju, D., Ma, L., Ren, R., \& Zhang, Y. (2019). Empowered to Break the Silence: Applying SelfDetermination Theory to Employee Silence. Frontiers in Psychology. http://dx.doi.org/ 10.3389/ fpsyg.2019.00485

21. Kebriaei, A., Rakhshaninejad, M., \& Mohseni, M. (2014). Influence of Psychological Empowerment on Organizational Commitment among Medical Employees in a Hospital Setting. Bangladesh Medical Research Council Bulletin, 40(3), 107-112. https://doi. org/10.3329/bmrcb.v40i3.25232

22. Klaussner, S. (2012). Trust and Leadership: Toward an Interactive Perspective. Journal of Change Management, 12(4), 417-439. https://doi.org/10.1080/14697017.2 012.728766

23. Koh, W. K. L., \& Hia, H. S. (1997) The effects of interactive leadership on human resource management in Singapore's banking industry. The International Journal of Human Resource Management, 8(5), 710-719. https://doi. org/10.1080/095851997341478

24. Kutanis, R. Ö., \& Çetinel, E. (2014). Silence of women: A research on public schools. Amme İdaresi Dergisi, 47(1), 153-173. Retrieved from https://www.researchgate.net/ publication/286229196_Silence_ of_Women_A_Research_on_Public_Schools

25. Lawton, A., \& Páez, I. (2014). Developing a Framework for Ethical Leadership. Journal of Business Ethics, 130(3), 639-649. https://doi. org/10.1007/s10551-014-2244-2

26. Legault, L. (2017). SelfDetermination Theory. In V. 
Zeigler-Hill \& T. K. Shackelford (Eds.), Encyclopedia of Personality and Individual Differences. Springer, Cham. https://doi.org/10.1007/9783-319-28099-8_1162-1

27. Linuesa-Langreo, J., Ruiz-Palomino, P., \& Elche-Hortelano, D. (2018). Integrating Servant Leadership into Managerial Strategy to Build Group Social Capital: the Mediating Role of Group Citizenship Behavior. Journal of Business Ethics, 152, 899-916. https://doi.org/10.1007/s10551-0183823-4

28. Llorente-Alonso, M., \& Topa, G. (2018). Prevention of Occupational Strain: Can Psychological Empowerment and Organizational Commitment Decrease Dissatisfaction and Intention to Quit? Journal of Clinical Medicine, 7, 450. https://doi.org/10.3390/ jcm7110450

29. Luthans, F., \& Youssef-MorganMorgan, C. M. (2017). Psychological Capital: An Evidence-Based Positive Approach. Annual Review of Organizational Psychology and Organizational Behavior, 4, 339-366. https://doi.org/10.1146/annurevorgpsych-032516-113324

30. Luthans, K. W., \& Jensen, S. M. (2005). The Linkage between Psychological Capital and Commitment to Organizational Mission: A Study of Nurses. JONA: The Journal of Nursing Administration, 35(6), 304-310. https://doi.org/10.1097/00005110200506000-00007

31. Masoomi, R., Yazdanpanah, A., \& Jafary, H. (2018). Identification of Factors Affecting Organizational Silence from the Viewpoint of Middle Managers of Shiraz University of Medical Sciences: A Qualitative Study. Shiraz E-Medical Journal, 20(4), e80110. https://doi. org/10.5812/semj.80110

32. Mirmohhamdi, S., \& Marefat, A. (2014). The Effect of Perceived Justice and Organizational Silence on Organizational Commitment. International Review of Management and Business Research, 3(3), 17731789. Retrieved from https:/www. semanticscholar.org/paper/TheEffect-of-Perceived-Justice-andOrganizational-Mirmohhamdi-Mar efat/68012c82f99d68e9c821b887cf6 df890847767c2
33. Mo, S., \& Shi, J. (2015). Linking Ethical Leadership to Employee Burnout, Workplace Deviance and Performance: Testing the Mediating Roles of Trust in Leader and Surface Acting. Journal of Business Ethics, 144(2), 293-303. https://doi. org/10.1007/s10551-015-2821-Z

34. Mollamohammadrafie, H. (2019). The Effect of Psychological Empowerment and Organizational Trust on Affective Commitment Evidence from Padjadjaran University, Bandung, Indonesia. International Journal of Scientific \& Technology Research, 8(1), 63-69. Retrieved from https:// www.ijstr.org/final-print/jan2019/ The-Effect-Of-Psychological-Empowerment-And-OrganizationalTrust-On-Affective-CommitmentEvidence-From-Padjadjaran-University-Bandung-Indonesia.pdf

35. Northouse, P. G. (2013). Leadership Theory and Practice (6th ed.). SAGE. Retrieved from https://www.academia.edu/22270113/Leadership_ Theory_and_Practice_6th_editi.

36. Ouyang, Z., Sang, J., Li, P., \& Peng, J. (2015). Organizational justice and job insecurity as mediators of the effect of emotional intelligence on job satisfaction: A study from China. Personality and Individual Differences, 76, 147-152. https://doi. org/10.1016/j.paid.2014.12.004

37. Pan, J., Quan, L. N., Zhao, Y., Peng, W., Murali, B., Sarmah, S. P., ... \& Yassitepe, E. (2016). Highly efficient perovskite-quantum-dot light-emitting diodes by surface engineering. Advanced Materials, 28(39), 8718-8725. https://doi. org/10.1002/adma.201600784

38. Rabelo, V. C., Holland, K. J., \& Cortina, L. M. (2019). From distrust to distress: Associations among military sexual assault, organizational trust, and occupational health. Psychology of Violence, 9(1), 78-81. https://doi. org/10.1037/vio0000166

39. Rego, A., Sousa, F., Marques, C., \& Pina e Cunha, M. (2012). Authentic leadership promoting employees' psychological capital and creativity. Journal of Business Research, 65(3), 429-437. https://doi.org/10.1016/j. jbusres.2011.10.003
40. Şahin, D. R., Çubuk, D., \& Uslu, T. (2014). The Effect of Organizational Support, Transformational Leadership, Personnel Empowerment, Work Engagement, Performance and Demographical Variables on the Factors of Psychological Capital. EMAJ: Emerging Markets Journal, 3(3), 1-17. https://doi.org/10.5195/ emaj.2014.49

41. Sekaran, U. (2006). Research Methods for Business: A SkillBuilding Approach. New York: John Wiley \& Sons.

42. Sekaran, U., \& Bougie, R. (2015). Research Methods for Business: A Skill-Building Approach (6th ed.). Wiley. Retrieved from https://www. amazon.com/Research-MethodsBusiness-Skill-Building-Approach/ dp/111994225X

43. Spence Laschinger, H. K., \& Fida, R. (2014). New nurses burnout and workplace wellbeing: The influence of authentic leadership and psychological capital. Burnout Research, 1(1), 19-28. https://doi. org/10.1016/j.burn.2014.03.002

44. Sunshine, J., \& Tyler, T. R. (2003). The Role of Procedural Justice and Legitimacy in Shaping Public Support for Policing. Law and Society Review, 37(3), 513-548. Retrieved from https://www.jstor. org/stable/1555077

45. Wang, X., Liu, L., Zou, F., Hao, J., \& Wu, H. (2017). Associations of Occupational Stressors, Perceived Organizational Support, and Psychological Capital with Work Engagement among Chinese Female Nurses. BioMed Research International, 1-11. https://doi. org/10.1155/2017/5284628

46. Wright, T. A. (2003). Positive organizational behavior: an idea whose time has truly come. Journal of Organizational Behavior, 24, 437 442. https://doi.org/10.1002/job.197

47. Yim, H.-Y., Seo, H.-J., Cho, Y., \& Kim, J. (2017). Mediating Role of Psychological Capital in Relationship between Occupational Stress and Turnover Intention among Nurses at Veterans Administration Hospitals in Korea. Asian Nursing Research, 11(1), 6-12. https://doi.org/10.1016/j. anr.2017.01.002 